\title{
Process Standardization of Kamsa: a Smoked Dried Meat Product, Using Sensory Evaluation Method
}

\author{
Yusuf H. L ${ }^{1 *}$, Igwegbe A. $\mathrm{O}^{2}$, Idakwo P. $\mathrm{Y}^{2}$, Garba, $\mathrm{U}^{1}$ \\ ${ }^{1}$ Department of Food Science and Technology, Faculty of Agriculture, Bayero University Kano, Janbulo Second Gate Rd, Nigeria \\ ${ }^{2}$ Department of Food Science and Technology, Faculty of Engineering, University of Maiduguri, Maiduguri, Nigeria
}

DOI: $10.36348 /$ sjet.2020.v05i09.002

| Received: 31.08 .2020 | Accepted: 08.09.2020 | Published: 13.09.2020

*Corresponding author: Yusuf H. L

\section{Abstract}

This study was aimed at establishing a standardized method for the processing of a traditional product, Kamsa, with consistent qualities, for prospective industrial or commercial purposes. Three samples (K1, K2, and K3) from fresh skeletal muscles of cow were prepared using the most common traditional methods of kamsa preparation. For the purpose of comparison, the fourth sample (K4) was prepared from the same meat source but, by modification of established standard methods of food dehydration and preservation. Process standardization was carried out through sensory evaluation by 15 panelists on a nine point hedonic scoring system, with 9 and 1 being extremely liked and extremely disliked, respectively. Results indicated that, among all the kamsa samples (K1 to K4) standardized, samples $\mathrm{K} 4$ and $\mathrm{K} 1$ scored the highest means in all the parameters evaluated, but varied significantly $(\mathrm{P} \leq 0.05)$ in their aroma. A $t$-test comparison was further carried out between K1 and K4 samples, and the results also showed that K4 was the most preferred sample. It was concluded that the preparation method used for K4 sample could be adopted as a standard method for industrial or commercial preparation of high quality and safe kamsa.

Keywords: Kamsa, process standardization, skeletal muscle, sensory evaluation, smoke-drying.

Copyright @ 2020: This is an open-access article distributed under the terms of the Creative Commons Attribution license which permits unrestricted use, distribution, and reproduction in any medium for non-commercial use (NonCommercial, or CC-BY-NC) provided the original author and source are credited.

\section{INTRODUCTION}

Meat can be defined as edible animal flesh, including processed or manufactured products derived from such tissues [1-3]. It had long been known for its nutritive value, and its protein profile consists of all amino acids that have been described as essential in human nutrition [4-6]. Meat is also a highly perishable food which needs proper handling and preservation if it is to have a long shelf life and retain a desirable quality and nutritional values $[2,7]$.

In Nigeria, the meat supply situation remains critical in spite of the relatively large animal population of more than 22 million sheep and 14 million cattle. The average Nigerian consumes $3.89 \mathrm{~g} / \mathrm{h} / \mathrm{d}$ of animal protein, which is less than the $34 \mathrm{~g} / \mathrm{h} / \mathrm{d}$ recommended by FAO [8, 9]. The existing conditions for slaughtering meat animals and meat handling, particularly in the rural areas, usually result to quality deterioration and post-harvest losses of meat. Meat is either consumed as a component of kitchen-style food preparations or as processed meat products. The major methods of preserving meat include freezing, smoking, drying, chemical preservation and heat treatment such as canning $[10,11,2,12,13]$. Use of an appropriate preservation technique offers opportunity of overcoming the two main constraints to a better supply of livestock products, namely availability and affordability $[13,3]$. When processing meat locally, the intention is to cook or partially cook, reduce moisture content, or impart flavour to the meat product. However, a combination of these methods is often used. For instance, hot smoking method is usually adopted in the preparation of popular Nigerian meat products such as Balangu, Tsire, Dambun nama, Kundi, Suya and Kamsa [14-21]. The use of intense drying heat during the processing of these products is necessary in the expulsion of moisture to preserve the product for a longer storage period [3].

Kamsa is common to the North Eastern part of Nigeria. It is a smoked-dried meat product free of additives or seasonings. It is locally processed and stored in earthenware pots for further processing and consumption. The Kamsa produced by the local producers is usually made from the meat of the hind quarters of the animal. Due to lack of facilities for its bulk processing, and its high potential for moisture 
absorption once exposed to high relative humidity [22, 3 ], there is no trading of the product even in the local markets within the production areas. It is usually produced in households as an inexpensive means of preserving excess meat, or for the preferred flavor it imparts to certain meals. It also serves as a source of good quality protein. To ensure the supply of Kamsa to high demand areas in a shelf-stable form, effective processing methods that can be replicated to give a high quality product need to be established. This requires standardization of the existing methods, which will generate fundamental data that can also serve as a basis for a large scale processing. This study was therefore aimed at standardizing the production methods of Kamsa using sensory evaluators (taste panelists) to ascertain the consistency in the quality characteristics of the final products.

\section{MATERIALS AND METHODS Processing of Kamsa}

Fresh beef from the skeletal muscle of the hind quarters of the slaughtered animal, with an average moisture content of $70 \%$ was used to produce the samples utilized in the present study. Three popular traditional methods differing in their processing procedures were identified and selected for the preparation of each of the three distinct samples of Kamsa: K1, K2, and K3 (Figures 1a - c). Each of the three samples was prepared with the aid of a traditional Kamsa producer who is familiar with the particular method. The three samples varied in strip lengths and thicknesses, drying time and final moisture contents (Table-1). The processing methods also varied in some aspects like the amounts of fat trimmed off from the raw material, distance from the heat source, the intensity of the smoke used and period of exposure to the smoke and heat source (Table-1). Similarly, and for the purpose of comparison (standardization), a method modified from a combination of both the traditional procedures of Kamsa preparation and standard food dehydration and preservation principles [23, 1, 24, 12], was used to produce the fourth sample of Kamsa: K4 (Figure-1d). The modifications included the use of meat from medium aged animal in good nutritional condition; complete trimming of fat and removal of visible contamination, washing and mopping up of surface moisture, use of more manageable strip sizes, generation of smoke from a semi-enclosed environment using hard wood shavings, measured distance between the source of smoke and the meat strips, and the use of a semi-automatic smoke and heat generator in the control of the entire smoke-drying process.

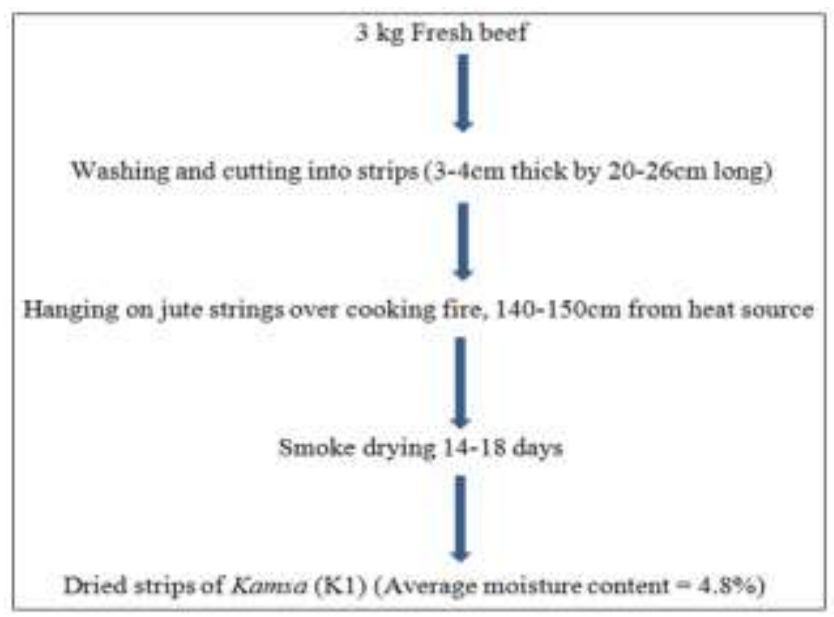

Fig-1a: Flow Chart for Traditional preparation of Kamsa, Method 1

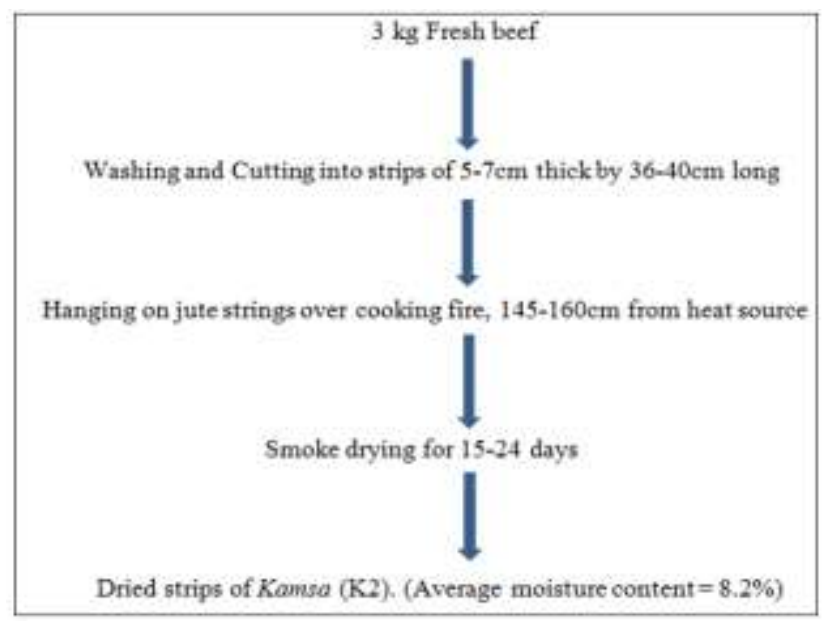

Fig-1b: Flow Chart for Traditional preparation of Kamsa, Method 2 


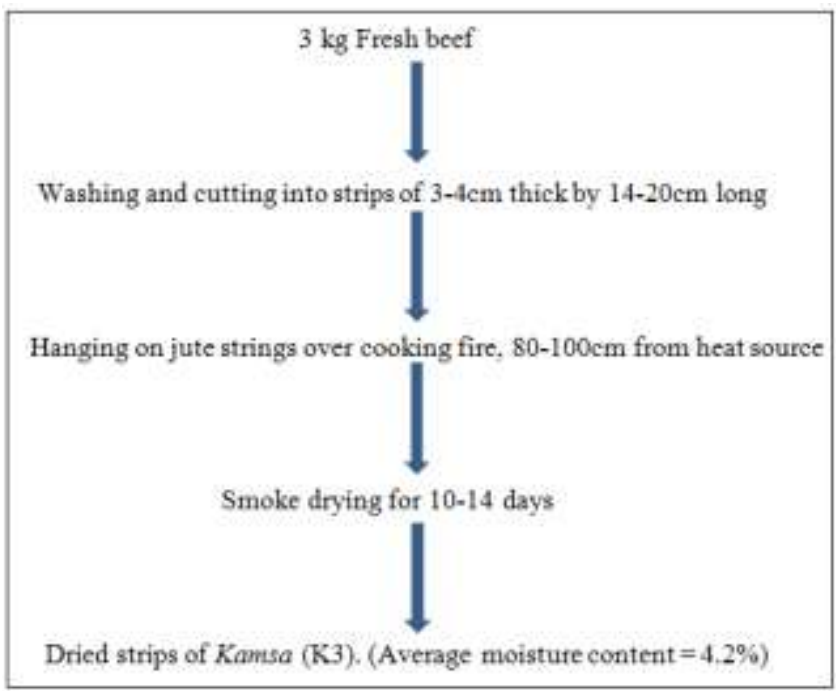

Fig-1c: Flow Chart for Traditional preparation of Kamsa, Method 3

Table-1: Summary of the Processing Parameters used in Kamsa Preparation in this Study

\begin{tabular}{|l|l|l|l|l|}
\hline $\begin{array}{l}\text { Sample } \\
\text { Code* }\end{array}$ & $\begin{array}{l}\text { Stripe Thickness } \\
(\mathbf{c m})\end{array}$ & $\begin{array}{l}\text { Distance from Heat } \\
\text { Source (cm) }\end{array}$ & $\begin{array}{l}\text { Drying Time } \\
\text { (Days) }\end{array}$ & $\begin{array}{l}\text { Final Moisture } \\
\text { Content (\%) }\end{array}$ \\
\hline K1 & 3.0 & 90 & 12 & 4.8 \\
\hline K2 & 6.0 & 155 & 19 & 8.2 \\
\hline K3 & 145 & 16 & 4.2 \\
\hline K4 & 62 & 02 & 6.4 \\
\hline \multicolumn{3}{|}{ K1 = Traditional preparation method 1; } \\
K2 = Traditional preparation method 2; \\
K3 = Traditional preparation method 3; \\
K4 = Modified / standardized preparation method 4
\end{tabular}

\section{Sensory Evaluation of the Products (Kamsa)}

The products from the traditional and modified methods, K1, K2, K3 and $\mathrm{K} 4$, respectively, were subjected to sensory assessments by 15 taste panelists. The panelists included adults (males and females) who are very familiar with the quality characteristics of the various types of Kamsa, and they were asked to score the samples based on a 9 point hedonic scale, with 9 and 1 being extremely liked and extremely disliked, respectively. The aim was to determine the processing method that produced the best quality and acceptable Kamsa. To make the samples safe and suitable for the sensory evaluation, $30 \mathrm{~g}$ of each of the samples (K1, K2, $\mathrm{K} 3$ and K4) were boiled for 20 minutes in $40 \mathrm{ml}$ of potable water containing $1 \mathrm{~g}$ of table salt, in a covered pan. The purpose of the boiling process was to quickly rehydrate the products and make them tender and easy to masticate. The parameters evaluated were texture, taste, aroma, colour and overall acceptability of the products.

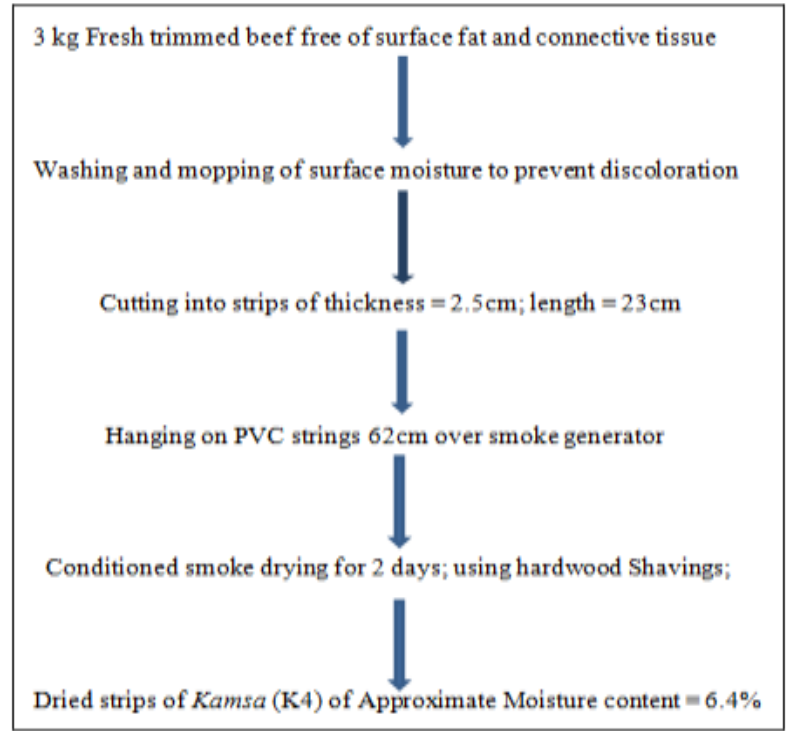

Fig-1d: Flow Chart for Modified preparation of Kamsa Method 4 


\section{STATISTICAL ANALYSIS}

Data obtained from the sensory evaluations were subjected to Uni-variate Analyses of Variance (ANOVA) to generate means that were further subjected to post-hoc multiple comparison test, using Duncan Multiple Range Tests (DMRTs) to determine significant differences between means at $95 \%(p \leq 0.05)$ confidence intervals [25]. In addition, two samples with the highest and closest mean scores from the parameters tested, were further subjected to another sensory evaluation. The two samples were presented to the same group of taste panelists using different codes but on the same 9 point hedonic scale as previously mentioned. The mean scores from this latter evaluation were subjected to a $t$-test to ascertain which of the two samples was most preferred and recommendable [26].

\section{RESULTS AND DISCUSSIONS}

The scores recorded from the sensory assessments of the four Kamsa products prepared and used for process standardization in this study are presented in Table-2. From the table, it can be observed that the parameters with the highest mean scores, 8.47 and 8.20, were texture and taste of sample K4, respectively. These values are however, not significantly different $(\mathrm{P} \geq 0.05)$ from those of sample $\mathrm{K} 1$, which are 7.53 and 8.00 , respectively. This is because the drying time, temperature, and water activity influenced the final product quality as observed by other researchers including Roquerol et al., [27], Okos et al., [23]; and, most recently, Abdullahi et al., [28] in a deep fried and stored Sallah meat. Furthermore, samples $\mathrm{K} 4$ and $\mathrm{K} 1$ were subjected to the shortest drying times and as sample $\mathrm{K} 4$ had the lowest strip thickness, the rate of moisture transfer from the strips during the drying process was higher.

Table 2: Sensory Scores of Kamsa Samples used for Process Standardization ${ }^{1}$

\begin{tabular}{|c|c|c|c|c|c|}
\hline \multirow[t]{2}{*}{ Sample Code ${ }^{3}$} & \multicolumn{5}{|c|}{ Organoleptic Parameters Scored $^{2}$} \\
\hline & Texture & Taste & Aroma & Colour & Overall Acceptability \\
\hline K1 & $7.53 \pm 0.62^{\mathrm{ab}}$ & $8.00 \pm 0.73^{\mathrm{ab}}$ & $6.80 \pm 0.65^{b}$ & $8.07 \pm 0.68^{\mathrm{a}}$ & $7.40 \pm 0.53^{\mathrm{ab}}$ \\
\hline $\mathrm{K} 2$ & $6.47 \pm 0.62^{\mathrm{c}}$ & $7.07 \pm 0.57^{\mathrm{c}}$ & $6.13 \pm 0.75^{b}$ & $6.93 \pm 0.68^{\mathrm{cb}}$ & $6.67 \pm 0.79^{b}$ \\
\hline K3 & $6.80 \pm 0.65^{\mathrm{bc}}$ & $7.27 \pm 0.68^{\mathrm{bc}}$ & $6.87 \pm 0.72^{\mathrm{ab}}$ & $7.13 \pm 0.96^{\mathrm{bc}}$ & $6.93 \pm 0.68^{b}$ \\
\hline K4 & $8.47 \pm 0.95^{\mathrm{a}}$ & $8.20 \pm 0.65^{\mathrm{a}}$ & $7.80 \pm 0.99^{\mathrm{a}}$ & $7.93 \pm 0.77^{\mathrm{ab}}$ & $8.30 \pm 0.60^{\mathrm{a}}$ \\
\hline
\end{tabular}

On the other hand, samples K2 and K3 scored the lowest means with regards to texture and taste, and the values were significantly different $(\mathrm{P} \leq 0.05)$ from those of sample K4 (Table-2). The samples, K2 and K3, had the longest drying times and they were placed farther away from their heat sources. These two factors caused a dense structure in the two samples that resulted in reducing their porosity. This latter observation was in line with those of Potter and Hotchkiss [29] and Menkov and Durakova [30]. This phenomenon made the water absorption capacity of the resultant product very low and tougher in texture, even after rehydration. It has been observed that, the structure, density, and particle size of dehydrated foods play an important role in their water absorption capacities during rehydration, which increases with decreasing particle size $[31,32,3]$. Also, the ease of reconstitution has long been observed to be greatly affected by physical shrinkage and distortion of cells and capillaries during the dehydration process, as well as by chemical or physicochemical changes at the colloidal level [33, 24]. A less dense product will absorb water and reconstitute quicker, and will closely resemble the original material, and therefore becomes more acceptable to consumers $[30,24]$. Texture is one of the key attributes of foods, which is used to define product quality and acceptability. Food texture can be defined by the way in which the various constituents and structural elements are arranged and combined into a micro- and macrostructure, and by the external manifestations of this structure, in terms of flow and deformation. Texture measurements are used throughout the food value chain to monitor and control quality, from harvest to assessing the impacts of postharvest handling and processing on shelf life and consumer acceptance. Postharvest handling and processing conditions such as storage temperature have been observed to have a significant influence on the textural properties of meat [34]. Meat texture is, however, usually described in terms of tenderness or the lack of it - toughness. This obviously is related to the ease with which a piece of meat can be cut with a knife or with the teeth.

Similarly, in terms of the product aroma, the highest mean score (7.80) was recorded in sample K4 that had the least processing time (Table-2), though it was not significantly different $(\mathrm{P} \geq 0.05)$ from that of sample K3 (6.87), but it varied significantly $(P \leq 0.05)$ when compared with those of samples K1 (6.80) and K2 (6.13). The difference in aroma could be due to the thicker dimension of $\mathrm{K} 2$ and its greater distance from the source of heat and smoke as indicated in Table-1, both of which prolonged the drying time, thereby allowing putrefactive activities to take place before drying process was completed. Putrefaction could be as 
results of growth and activities of some spoilage microorganisms that were able to degrade the tissue glycogens, while others metabolized the proteins [1]. The observed difference in aroma could also be as a result of breakdown of fat into some volatile fatty acids, since the fats on those samples were not completely trimmed off prior to the drying process, as it is practised in the traditional method of Kamsa processing. The objectionable aroma could be due to the combined effects of these two factors. Fat decomposition could be in the form of hydrolytic rancidity because of the greater quantity of saturated fats in red meats [35]. Hydrolytic rancidity is catalyzed by the enzyme lipase in the presence of water, which breaks down glyceride component of a fat into free fatty acids and glycerol, fat oxidation contributes immensely to flavour and odour deterioration, especially in smoked-dried meat [36, 37]. Meat is another food in which the flavor is developed during heating from precursors present in the meat; this occurs in a Maillard-type browning reaction. The overall flavor impression is the result of the presence of a large number of nonvolatile compounds and the volatiles produced during heating.

With regards to the acceptability of the products, sample K4 had the most acceptable aroma and, it was placed at the shortest distance from the source of heat during the smoking operation. This could have provided the heat treatment that is usually sufficient to destroy the lipase enzymes that are responsible for catalyzing hydrolytic rancidity, which affects taste and odour [37] that is especially observable in meats [35].

In terms of colour, sample $\mathrm{K} 1$ was scored higher (8.07) than K4 (7.93), although the two means did not vary significantly $(P \geq 0.05)$. The lowest mean scores with regards to colour of the products were recorded in samples K2 and K3 (Table-2). The lack of preference shown to the colour of sample K2 and K3 could be as a result of the intensity of the heat and exposure of the meat pigment (or the myoglobin) to oxygen during processing of the two samples. The colour of myogloben in the fresh meat cut from an animal that is properly rested prior to slaughter is usually purple, but upon exposure to oxygen in the air it turns to bright red due to formation of oxymyoglobin $[29,2,6]$. Consequently, the prolonged exposure to air of samples K2 and K3, of 19 and 16 smoking days, respectively, may have resulted to an excessive oxidation of oxymyoglobin, converting it to metmyoglobin, which is responsible for brownish colour of the products. Moreover, other factors like the slowly removal of moisture and lack of adequate heat from the source (due to the placement of the drying products far away from the heat source, Table-1), could have allowed progressive bacterial growth on the meat, which changed the metmyoglobin to a darker and unattractive colour $[1,6]$. It is also important to note that the smoking process for $\mathrm{K} 2$ and $\mathrm{K} 3$ samples was not controlled, and this could have resulted to the darker colour of the products.

Finally, the result of the t-test comparison between the two products, $\mathrm{K} 1$ and $\mathrm{K} 4$, which have very close mean scores, is presented in Table-3. The two means varied significantly $(\mathrm{P} \leq 0.05)$, with sample $\mathrm{K} 4$ recording the highest scores in all the parameters investigated. This indicates that the procedures used in the preparation of sample $\mathrm{K} 4$ in this study could be adopted as a standardized method for safe and high quality Kamsa production in Nigeria. There is urgent need therefore, to disseminate this finding among the local and/or traditional Kamsa producers in the country.

Table-3: Comparison between the Means of the Two Preferred Samples of Kamsa ${ }^{1}$

\begin{tabular}{|c|c|c|c|c|c|}
\hline \multirow[t]{2}{*}{ Sample Code $^{3}$} & \multicolumn{5}{|c|}{ Organoleptic Parameters Scored $^{2}$} \\
\hline & Texture & Taste & Aroma & Colour & Overall Acceptability \\
\hline K1 & $6.73 \pm 0.80^{b}$ & $7.13 \pm 0.96^{b}$ & $6.47 \pm 0.62^{b}$ & $6.47 \pm 0.62^{\mathrm{a}}$ & $7.07 \pm 0.77^{\mathrm{b}}$ \\
\hline K4 & $8.07 \pm 0.60^{\mathrm{a}}$ & $8.67 \pm 0.91^{\mathrm{a}}$ & $7.53 \pm 0.62^{\mathrm{a}}$ & $7.33 \pm 0.51^{\mathrm{a}}$ & $8.07 \pm 0.57^{\mathrm{a}}$ \\
\hline
\end{tabular}

\section{CONCLUSION}

The desirable pigments and flavor compounds in meat may undergo both acceptable and unacceptable changes during preparation, depending on the method employed. Thus, improper method of preparation can result in quality losses. This study has proved that the use of proper preparation techniques which include manageable stripe thicknesses or sizes, measured distances from the heat source and controlled drying time or period, can produce good quality Kamsa. The control of these parameters during the preparation of sample K4 has resulted to the best quality and safe
Kamsa, and therefore has been accepted as a standardized method for a commercial Kamsa production.

\section{ACKNOWLEDGEMENTS}

The authors highly appreciate the Department of Food Science and Technology, Faculty of Agriculture, Bayero University Kano, Kano State, and the Department of Food Science and Technology, Faculty of Engineering, University of Maiduguri, Borno State; for providing the resources and conducive research facilities used in this study. 
Yusuf H. L et al., Saudi J Eng Technol, September, 2020; 5(9): 330-336

Conflicts of Interest: The authors declare no conflicts of interest regarding the publication of this paper.

\section{REFERENCES}

1. Murano, P. S. (2003). Understanding Food Science and Technology. Washworth Cengage Learning, Belmont, CA., USA.

2. Knipe, C. L., \& Rust, R. E (2010). Thermal Processing of Ready-to-Eat Meat Products. WileyBlackwell, A John Wiley \& Sons, Ltd Publication, USA.

3. Yusuf, H. L., Ismail, B. B., Igwegbe, A. O., Idakwo, P. Y., \& Bako, H. K. (2020). Moisture Sorption Studies of Kamsa: A Smoke-dried Meat Product Stored Over a Period of Six Months, Using GAB and BET Models. European Journal of Engineering Research and Science, 5(4):501509.

4. Biesalski, H. K., \& Nohr, D. (2009). The nutritional quality of meat. In: Kerry, J. P., \& Ledward, D. (Eds). Improving the Sensory and Nutritional Quality of Fresh Meat, $1^{\text {st }}$ Edn. Woodhead Publishing Ltd, Cambridge, England.

5. Collins, S., Gerrad, L. E., \& Hunt, A. K. (2011). Changes in Amino Acid Profile of Venison and Mutton stored at $-2^{\circ} \mathrm{C}$ for eight weeks. Journal of Biotechnology, 7(16): 2901

6. Olaoye, O. J. (2011). Meat: An overview of its composition, biochemical changes and associated microbial agents. International Food Research Journal, 18(3):877-885.

7. Igwegbe, A. O., Idakwo, P. Y., Yusuf, H. L., Agbara, G. I., Maijalo, A. I., \& Abubakar, F. (2019). Effects of sodium citrate and garlic on organoleptic properties, proximate composition, free fatty acid and thiobarbituric acid levels of treated smoke-dried meat stored at ambient temperature. CPQ Medicine, 5(5):2-14.

8. Zulyadaini, H., \& Yusuf, H. L. (2015). Chemical and Microbiological Composition of Salted, Sundried, Beef and Mutton. Biological and Environmental Sciences Journal for the Tropics, 12(1): 630-633.

9. Yusuf, H. L., Igwegbe, A. O., Idakwo, P. Y., Ahmad, G., \& Sani, A. (2020). Physico-chemical and Microbiological Analyses of a Smoke-dried Meat Product (Kamsa) During Six Months Storage Period. Agricultural Research and Technology Open Access Journal, 24(2):48-52.

10. Thippareddi, H., \& Sanchez, M. (2006). Thermal processing of meat products. In: Thermal Food Processing: New Technologies and Quality Issues. Sun, D. W. (Ed.), Taylor and Group CRC Press, New York. 156-192.

11. Gunter, H., \& Hautzinger, P. (2007). Meat Processing Technology for Small to Medium Scale Producers. Food and Agricultural Organization (FAO) of the United Nations. Regional office for Asia and the Pacific, Bangkok. Thailand.
12. Vaclavik, V. A., \& Christiana, E. W. (2014). Essentials of Food Science, $4^{\text {th }}$ Edition. Springer Science + Business Media Inc., New York, USA.

13. Igwegbe, A. O., Kassum, A. L, Maina, F. J., Bristone, C., Abubakar, F., Imam, H. O., Lawan, H. K., \& Adam, F. M. (2019). Effects of sodium citrate and garlic on $\mathrm{pH}$ and microbial stability of smoke-dried meat stored at ambient temperatures. In "Health, Environment and Sustaniable Development: A Book of Readings in Honour of Professor Ibrahim Njodi, Chapter 23" Opara, J. A. (Ed.). University of Maiduguri Press, http://www.unimaid.edu.ng. 226-240.

14. Yusuf, A., Abdulhamid, T., \& Hussain, I. J. (2012). Isolation and identification of bacteria associated with balangu (roasted meat product) sold in Bauchi, Nigeria. Journal of Pharmacy, 2(6), 38-39.

15. Eke, M. O., Ariahu, C. C., Okonkwo, T. M., (2012). Production and Quality Evaluation of Dambu-Nama, A Nigerian Dried Meat Product. Nigerian Food Journal, 30(2).

16. Manyi, M. M., Idu O. F., \& Ogbonna, I. O. (2014). Microbiological and parasitic quality of Suya (rosted beef) sold in Makurdi, Benue State, Nigeria. Afr J Microbiol Res. 8(35):3235-3242.

17. Samuel, O., Obika, I., Odibo, F., \& Orji, M. (2015). An assessment of the bacteriological quality of Tsire-Suya (Grilled Beef) sold in Awka, Nigeria. Ann J Life Sci Res. 3(4):287-292.

18. Nwakanma, C., Unachukwu, M. N., \& Momoh, O. R. (2015). Bacteriological examination of suya meat sold in Enugu metropolis. World Journal of Pharmaceutical Research. 4(12): 61-70.

19. Adeyeye, S. A. (2016). Quality and safety assessment of sun dried meat product (kundi) from Ibadan, Oyo state, Nigeria. Cog Food Agric. 2(1):1209074.

20. Egbebi, O. A., \& Muhammed, A. A. (2016). Microbiological analysis of ready-to-eat suya meat sold in Owo, Ondo State, Nigeria. Int J Innov Biochem Microbiol Res. 4(2):11-15.

21. Abdullahi, F. S., Igwegbe, A. O., Bello, A. B., Abashe, S., Adam, I. K., \& Badau, M. H. (2019). Assessment of Microbial Quality of BalanguDipping Water from Six Outlets in Wudil Town in Kano State, Nigeria. Int J Food Sci Technol. 9(2):1-12.

22. Yusuf, H. L., \& Abubakar, U. M. (2011). A Study of the Moisture Sorption Characteristics of Kamsa (a smoke dried meat product). Biological and Environmental Science Journal for the Tropics. 8(4).

23. Okos, M. R., Narsimhan, G., Singh, R. K., \& Weitnauer, A. C. (1992). Food Dehydration. In "Handbook of Food Engineering". Heldman, D. R., \& Lund, D. B. (Eds.). Marcel Dekker, New York, USA. 437-562. 
24. Shafiur Rahman, M. (Ed.). (2007). Handbook of Food Preservation, $2^{\text {nd }}$ Edition. CRC Press, New York.

25. Dean, A., Voss, D., \& Draguljic, D. (2017). Design and Analysis of Experiments, $2^{\text {nd }}$ Edn. Springer International Publishing, New York, USA.

26. Lawless, H. J., \& Heymann, H. (2010). Sensory Evaluation of Food: principles and Practice. $2^{\text {nd }}$ Edition. Springer Science+Business Media. New York, USA.

27. Rouquerol, F., Rouquerol, J., Sing, K. (1999). Adsorption by Powders and Porous Solids. Academic Press London, Great Britain.

28. Abdullahi, F. S., Igwegbe, A. O., Bello, A. B., Igwegbe, I. U., Badua, M. H., Abashe, S., \& Ali, Z. (2020). A comparative study of bacteriological load of freshly fried and stored Sallah meat from Danbata Local Government Area of Kano State, Nigeria. International Research Journal of Public and Environmental Health, 7(4): 117 - 126.

29. Potter, N. N. and Hotchkiss, J.H. (1998). Food Science. Fifth Edition. Springer Science+Business Media, New York, USA.

30. Menkov, N. D., \& \& Durakova, A. G. (2007). Moisture Sorption Isotherms of Sesame Flour at Several Temperatures. Food Technol Biotechnol, 45(1):96-100.

31. Roos, Y. H., Finley, J. W., \& deMan J. M. (2018). Water. In: "Principles of Food Chemistry, $4^{\text {th }}$
Edition”. deMan, J. M., Hurt, W. J., Finley, J. W., \& Lee, C. Y. (Eds.). Springer International Publishing AG. Cham. Switzerland. 1-38.

32. Jangam, S.V., Law, C. L., \& Mujumdar, A. S. (2010). Drying of Foods, Vegetables and Fruits, Volume 1. ISBN - 978-981-08-6759-1, Published in Singapore.

33. Kim, N. S., Kim, S. J., \& Lee, G. M. (1998). Clonal variability within dihydrofolate reductasemediated gene amplified Chinese hamster ovary cells: Stability in the absence of selective pressure. Biotechnology and Bioengineering, 60(6), 679-688.

34. Farag, K. W., Lyng, J. G., Morgan, D. J., \& Cronin, D. A. (2009). Effect of low temperatures $\left(-18\right.$ to $\left.+5^{\circ} \mathrm{C}\right)$ on the texture of beef lean. Meat Science, 81: 249-254.

35. Gibson, M., \& Newsham, P. (2018). Lipids, Oils, Fats, and Extracts; In "Food Science and Culinary Arts". Academic Press, London, UK. 323-340.

36. Velasco, J., Dobarganes, C., \& Marquez-Ruiz, G. (2010). Chemical Deterioration and Physical Instability of Foods and Beverages: In "Oxidative Rancidity in Foods and Food Quality". Woodhead Publishing Series, London, UK. 3-32.

37. Finley J. W., \& deMan, J. M. (2018). Lipids. In "Principles of Food chemistry, Fourth Edition". deMan, J. M., Finley, J. W., Hurst, W. F., \& Lee, C. Y. (Eds). Springer International Publishing AG, Switzerland. 39-116. 